\section{Summary}

The Writer Antanas Skripkauskas Library

Gražina NARBUTAITE

Antanas Skripkauskas (1904-1941) was a write teacher and active member of the Resistance Movemen From 1924 to 1926 he studied at Siauliai Teachers Semnary and worked in various primary schools of Lithuan after that. He contributed to periodicals and wrote fou novels (1931-1937). He entered Vilnius Pedagogical Institute for Lithuanian Language and Literature studies. A. Skripkauskas was a member of the underground organization established in 1940 against the Soviet Occupation In 1941 he was arrested, deported to Gorkij (Russia) and

For a long time literary works of A. Skripkauskas were withrawn from the libraries, thus, no information could be found about him.

Antanas and Ona Skripkauskai, both teachers, owned a sufficiently rich and universal by its nature library. In 1944 Ona Skripkauskienè brought it to Šiauliai and stored together with the books of her relatives. After she passed away in 1974, one part of the library was divided among two sons but the sufficient part of publications was brought away as the waste paper.

The article is written on the grounds of the set of 41 book preserved by Romualdas Skripkauskas (A. Skripkauskas' son). The well-known publishers in Germany, France and Russia issued these publications from 1844 to 1938. Journals and books reveal a broad scale of subjects including philosophy, religion, pedagogics, mathematics, nature science, music, fiction and history. The publications include one Icelandic, four English and thiteLithuanian creations. Eight books have dedications or inscriptions made by their owners and four books ar red with the seals of somers and four books are

ese publications allows contemplating about the whole personal library, which been entirely unknown until now.

In 2004 the writer's son R. Skripkauskas donated this collection of publications to Šiauliai Aušros Museum and Siauliai District Museum of Literature and Art

UDK $070.421(73)(=882)(092)$

\title{
Laikraščio „Garsas Amerikos lietuviu“" redaktoriai 1894-1899 metais
}

Skirmantè KVIETKAUSKIENE

Lietuvos nacionaline Martyno Mažvydo biblioteka, Gedimino pr. 51, LT-01504 Vilnius, el. p. s.kvietkauskiene@Inb.It

Rengiant spaudai „Lietuvos bibliografija. Serija C. Lietuviškı̨ periodiniu leidiniu publikacijos, $1897^{\prime \prime}$ ir aprašant leidinius, susiduriama su šiais klausimais: kas straipsnio autorius, kas vertè vieną ar kita kūrini kas tuo metu verte vieną ar kila kưrini, kas tuo metu iškilo dèl 1894-1899 m. èjusio laikiškilo dél 1894-1899 m. ejusio laikdaktoriu.

894 m. laikrašti ,Garsas Amerikos lietuvių" pradèjo leisti A. Milukas

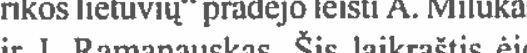
ir J. Ramanauskas. Sis laikrastis ejo vetoje bikno liumi no pimojo num riumi nuo pirmo numerio, isleisto $1894 \mathrm{~m}$. spalio 2 diena, buvo pakvestas K. Senkus . Redaktoriavo jis neilgai. $1895 \mathrm{~m}$. sausio 15 dieną isejusiame numeryje $K$. Senkus praneša, kad „su siuomi numeriu „Garso A.L. atsitraukiu nuo redagavojimo sio laikraščio". Tokias zinias pateike laikraštis. Dar daugiau painiavos atsiranda ieškant informacijos apie šio laikraščio redaktorius bibliografiniuose šaltiniuose. Antai P. Lavinskas knygoje „Amerikos lietuviu laikraščiai: 1879

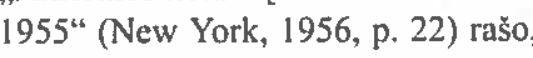
kad pirmus metus „Garsą Ameriko lietuviu" redagavo J. Ramanauskas if visiškai nemini K. Senkaus. Pagal kitus šaltinius bei pati laikrašti, J. Ramanauskas pradžioje buvo tik leidèjas, 0 redaguoti laikraštti èmési po K. Senkaus atsistatydinimo ${ }^{3}$. Jis redagavo $1895 \mathrm{~m}$. 4-9 numerius, kol buvo pakviestas daktaras J. Stupnickas. Tame pačiame
Gaikraščio „Garsas Amerikos lietuviü“ numerio", o 1896 m. - iki 24 nunumeryje, kuriame buvo paskelbtas merio $0^{10}$. Ar V. Biržiška klydo? XIX redaktoriaus K. Senkaus atsistatydi- simtmecio pabaigoje nebuvo iprasta nimo laiškas, paskelbiama apie J. Ra- laikraščio metrikoje nurodyti redakmanausko paskyrimą redaktoriumi`. torius (tik Mažojoje Lietuvoje leidžiaLaikraštis „Saulè“" $1895 \mathrm{~m}$. sausio 24 muose laikraščiuose redaktoriai nudienos numeryje rašo, kad „ponas rodomi), todèl žiniu apie redaktorius Stupnickas, daktaras, apemi redakcija galime rasti tik straipsniuose, žinutèse. "Garso" išeinančio Šenandorije...". Apie J. Stupnicko redagavima po to Tikriausiai laikraščio „Saule“" kores- vienintelès žinutès „Naujoje gadynėje“ pondentas suklydo, nes tos pačios néra daugiau jokiu užuominu. Lieka lietuviu" yra naujojo redaktoriaus J dinimo redagavo laikrasti nes žinio Ramanauko vedamasis ${ }^{5} \mathrm{~V}$ Biř̌iška ${ }^{6}$ labai prieštaringos. Lietuviu encikrošo, kad $1895 \mathrm{~m}$. iki 8 numerio lonedija"ll reda

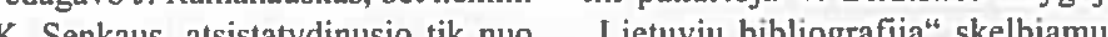
Kiojo num, alsis o 9 numero

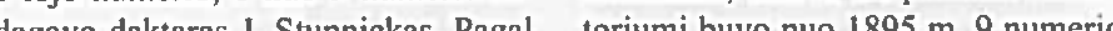
V. Biürosk 3 . 1874-191047, .

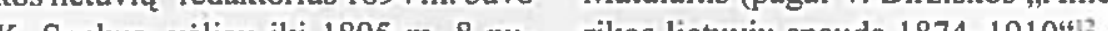
merio - J. Ramanauskas, o nuo 1895 nuo $1896 \mathrm{~m} .25$ numerio).

m. 9-ojo - J. Stupnickas. Apie J. Ra- Apie 1896 metais laikraščio remanausko atsistatydinima iš redak- daktorius straipsniu ir žinučiu nèra. toriaus pareigu laikraščiuose nèra ži- Tik birželio 19 dienos nenumeruotam niu, o apie daktarą J. Stupnicką numeryje ${ }^{13}$ yra redakcijos żinuté, kužurnalo „Nauja gadyné" 1895 m. 15 rioje pranesama, jog korespondenta numeryje rašoma, kad jis atsistatydina „norédami patalpinti kokią žinute iš laikraščio redaktoriaus ir Śnenandoro "Garse" privalo kreiptis prie p. J. teatro draugijos vadovo pareigu. Ži- Montvillo, kuris bus atsakančiu redaknant, kad šis žurnalo „Nauja gadyne““ toriumi tos ... dalies, kur patilps vienumeris turèjo išeiti nugpjuččio mènesi tinès žinios...... Tai leidžia suprasti, (èjo 2 kartus per ménesi), J. Stup- kad J. Montvila buvo atsakingas tik nickas tuo metu ir turèjo atsistatydinti. už laikraštyje spausdinamas žinutes V. Biržiška rašo, kad J. Stupnickas apie vietos ịvykius. Si skyrių jis redaredaktoriumi $1895 \mathrm{~m}$. buvo nuo 9 gavo neilgai, nes jau $1896 \mathrm{~m}$. liepos 9 
dieną laikraštyje „Saulè“ pranešam apie J. Montvilos atsistatydinima $a^{14}$.

$1897 \mathrm{~m}$. redaktoriumi praded

dirbti vienas iš leidèju - A. Milukas, jau baigęs Kunigu seminarija. V. Bir žiška ${ }^{\text {ts }}$ rašo, kad 1897 m. 1-26 nume rius redaguoja J. Montvila, o 27-53 numerius - A. Milukas. Bet apie J. Montvilą neužsimena nei „Lietuviu enciklopedija ${ }^{\text {"16 }}$, nei V. Biržiška ,Lietuvių bibliografijoje ${ }^{\text {"17 }}$ (abu šaltinia mini tik A. Miluka). Laikraščiuose apie J. Montvila, kaip „Garso Amerikos lietuvių" redaktoriu, žjiniu taip pat nèra tik 1899 m. yra dvi žinutės ${ }^{18}$, kuriose pranešama apie buvusio redaktoriaus išvykima is JAV, bet iš ju neažstrias J. Montvila buvo redaktorium

$1897 \mathrm{~m}$. laikraštyje Vienybé lis

tuvninku“"19 yra J. Kazakevič nuté, kurioje pranex pas atsisaké Tévynés myletoju Kaugijos literatürines komijos pareigu todèl $i$ jo via Parnati [ ] V. Stagara [V Š pas redaktorius Garo. Th. J. Kazakevičius galëjo ir nežinoti, kad V Šse kys buvo atsakomasis redaktorius.

' Senkus, K.J. ,Pašaukktas redagavoti „,Gars Amerikos lietuviq"..." // Garsas Amc[4].

2Senkus, K.J. „Su siuomi numeriu ,Garso A.L." atsitraukiu nuo redagavojimo sio laikraščio ..." / Garsas Amerikos lietuviu. - 1895, saus. 15 (Nr. 3), p. 20. Biržiska, V. Lietuviun bibliografija. - Kaunas, 1929. - D. 3, sklt. 897

riks lierikos lietuviu // Garsas Ame p. 20.

Mieli brolei!// Garsas Amerikos lietuviu-

1895, saus. 24 (Nr. 4), p. 25.

"Biržisiska, V. Lietuviu ..., sklt. 933.

Biržjsksa, V. Lithuanian publications in the
Pagal V. Biržišsos knygą „Lietuviu bibliografija", V. Slekys atsakomasis redaktorius buvo iki $1898 \mathrm{~m}$. kovo 31 d. (Nr. 13). Aprašant $1897 \mathrm{~m}$. laikrašt "Garsas Amerikos lietuviu" pastebèta, kad laikraščio metrikoje $V$. Şlekys (V. Stagaras), kaip atsakomasis redaktorius, pažymètas tik nuo birželio 12 dienos numerio ${ }^{20}$, o apie A. Miluk pateikta pastaba, kad jam galima siust korespondencija skirta laikrašciu Tokia praktika buvo iprasta to mo spaudoje kai pats redaktorius gaudavo visa laikraščiui skirta korespondencij. A. Milukas kip laikrasondencije pondencijos kavejas iki 32 usos gavejas, minimas nuo soma kad visa kore botiti, kiund vorespondencija tur  Milutas rak 1897 mu pradriumi buvo nuo pa Biřs. spauda 1874-1910" suklydo, kad J. spauda 1874-1910 suklydo, kad J. Montvila $1897 \mathrm{~m}$. redagavo $1-26 \mathrm{nu}$ meriss, nes daugiau niekur tai pat tinančiu žinių rasti nepavyko.

United States, 1874-1910 = Amerikos lietuvilu spauda, 1874-1910. - Chicago, 1994. - P. 216.

Garsas Liet. A." Shenandorije prastojo zeceriy - galliaus ir redaktoriaus ..." // Nauj Biržiska, V. Lietuviu . skl. 933 ${ }^{10}$ Ten pat, skJt. 966.

Lietuviu enciklopedija. - Boston, 1956. T. 7, p. 28

Birżskka, V. Lithuanian publications...

. Guodotiniems korespondentams pra

nesame ... Garsas Amenkos lietuvit

4 P. Montevila procinu 23], p [4].

atstojo "\# prociaunink - 1896, no ."Garso

28), p. [i]
1898-1899 melais laikrašti redagavo keli redaktoriai: A. Milukas, Matulaitis, o nuo $1898 \mathrm{~m}$. lapkričio 24 d. iki 1899 rugpjūčio 3 d. - B. Žindžius ${ }^{21}$. Nei Garse Amerikos lietuviư", nei kituose to meto laikrožčiuos aptikti žiniu apie redaktorius neparyo. Tik 1899 m. yra dvi jau cituos ż nutés apie buvusio laikrắio Ameriks livio laikrašcio „Garsa Montvilos išvykimą i Anglija.

Iš aptartų šaltinių matyti, kad laikraščio „Garsas Amerikos lietuviu" redaktoriais dirbo: nuo $1894 \mathrm{~m}$. spalio $2 \mathrm{~d}$. iki $1895 \mathrm{~m}$. sausio $15 \mathrm{~d}$. $-\mathrm{K}$. Senkus; nuo $1895 \mathrm{~m}$. sausio $24 \mathrm{~d}$. ik vasario $21 \mathrm{~d}$ - J. Ramanauskas; nuo $1895 \mathrm{~m}$. vasario $28 \mathrm{~d}$. iki rugpjūčio J. Stupnickas. Kas redagavo nuo 1895 m. rugpjū̌cio iki $1896 \mathrm{~m}$. birželio 2 d. nepavyko nustatyti. Nuo $1896 \mathrm{~m}$ birzelio 26 d. iki mety pabaigos redagavo V. Matulaitis, nuo 1897 iki 1898 m. pradžios - A. Milukas, véliau - vè $\checkmark$. Matulaitis, o nuo $1898 \mathrm{~m}$. lapkričio $24 \mathrm{~d}$. iki paskutinio numerio $1899 \mathrm{~m}$ rugpjūčcio 3 d. - B. Žindžius.

${ }^{3}$ Biržisksa, V. Lithuanian publications 16 Lietuviu enciklopedija ..

Biržiska, V. Lietuviu ..., sklt. 1009 „P. Jonas Montvila, buves ,"Garso A.I." redaktorius apleido Amerika ..." "// Garsas Amerikos lietuvil. - 1899, bal. 6 ( $\mathrm{Nr}$ 14), p. 108.

uvęs Garso red p. Jonas Montvila išlezynós. 109.

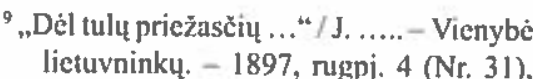
lietuvnin

Ślekys, V., The Lithuanian weekly ,Garsas Amenkos lietuviu" ..." V. Vtagaras / 12 (N. 24), p. [2].

:- Biržiska, V. Lietuvil ..., sktt. 1047, 1080.

UDK 002.2(474.5)(091)

\section{Vilčiu teikiantis leidinys}

Sigitas NARBUTAS

Lietuviu literatüros ir tautosakos institutas, Antakalnio g. 6, LT-10308 Vilnius, el. p. narbutas@ltti.lt.

Lietuviškieji slapyvardžiai : lictuviškos spaudos iki $1990 \mathrm{~m}$. slapyvardžiu savadas / Lietuvos Respublikos kultūros ministerija. Lietuvos nacionaline Martyno Mažydo bithor

Lietuviškos spaudos lotyniškais m̌̌menimis atgavimo šimtmečio minèimo meltis buvo surengta dur ajtmo me a is buvo surengta daug mets inicijuotas keliq paminklų kưrimas,

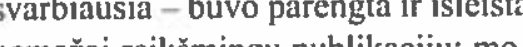
nemažal relnsmigu publikaciju. monografju, dokm strapsnit rinkiniu, spaudos draudima panaikint siekusių Lieltuvos sviesuolic rašlu î t. t. Is visuomenés démesi patraukusi siai progai skirth leidiniu galima pamineti Antano Tylos sudaryta dokumenty rinkini Lietuvin (spaudos dratdimo panaikinimo byla pinskienés sudarytus, o llonos Ciuzauskaites parengtus Petro Vileišio Rinktinius rastus ${ }^{2}$, straipsniu rinkinius Raidžit draudimo meta ${ }^{3}$, Žodžio laisvë̈, Benjamino Kaluškevičiaus i Kazio Misiaus sudarytą vardyną Lietuvos knygnešiai ir daraktoriai, 1864 $1904^{3}$, Gedimino Ilgūno knygą Knygnešit keliais ${ }^{b}$ autorių kolektyvo parengtą literatüros rodyklę Vincas Ku$\operatorname{dir}^{7} a^{7}$ ir $\mathrm{kt}$.

Visus šiuos leidinius finansiška rèmè Lietuviškos spaudos lotyniškais rašmenimis atgavimo šimtmečio $\mathrm{m}$ néjimo komisija, dèl suprantamų priežasčiu nuo $2005 \mathrm{~m}$. pradžios pakeitus pavadinima. Mat pasibaigus vien reikšmingo ivykio metinèms veikia prasideda kiti jubiliejiniai renginiai; visa tai sudaro valstybès puoselèjim reikalingą lietuviu modemiosios kulüros tradicijæ tad ir minetasis kolekyvas nuo $2005 \mathrm{~m}$. pradžios vadinasi uanistikos tradicifur imo komisija.

isijos paramos dèka buo išleistas kol kas reiksmingiousias is visu pasirodžiusiuju leidinys - Lietrvišlu slapyvardži savadas. Ta sho dinatis 8190 anciu ir apimantis 30950 lapyvardžiu Jo pirmajame tome papyvardias pasirasinejusius autorius pyvar (pavardes, kitos jurmos, vard, iijo mi vel jus a  ir vardo pirmoji raidè. Šio leidinio rengejus galima suprasti, nes jie neapsiribojo tik žinomais autoriais, o itraukè visus, pasirašiusius slapyvardžjais. Tačiau laikui bègant mûsu žinio apie praeities kûréjus gausẻja, duomenı atsiranda vis daugiau, todel ilgainiui ne vieno autoriaus biograma, taip dar pasipildys.

Antrasis veikalo tomas yra didžil lis: jame 1168 puslapiai. Tokiq̨ apim| sąlygojo itin gausi čia pateikiama medžiaga. Kiekvieno slapyvardži aprašă sudaro, be paties slapyvardžio, dar keli svarbūs elementai: autorius, slapyvardžiu pasirašyti kūriniai ir vienas šaltinis, atrinktas iš daugelio $\mathrm{jl}$ dentifikavusiuju. Kiek buvo idèta darbo, rengiant ši toma, liudija ispūdingos apimties Saltiniu (archyvu rankraštynu, knygu, periodiniu leidiniu), iš kuriu paimtos žinios apie slapyvardžius, sarašas. Beje, slapyvardžiu išskinimo šaltiniai, kaip ir daugelis kitu lapyvardžius liečiančiy klausimu (ju mamprata, vatojimo priežastys, darybos principai ir formos, lietuviu kultūrogu ir bibliografu atliktas darbas identifikuojant ir iprasminant juos) ide sudarytojo dr Jono Maxiulio straipsnyje, publikuotame veikalo pirmajame (ame.

Slapyvardžiu vartojimas kiek vienos tautos raštijoje būna susijęs tiek su bendro pobūdžio priežastimis, tiek paskiros valstybès ar kurios nor (religinès, politinès, ekonominės, kuluürinès ir pan.) bendrijos egzistavimo ypatybẻmis. Iš bendruju tokios raiškos motyvaciją lemiančiu priežasčiı galima nurodyti, pavyzdžiui, kai kurił vienuoliju regulose irašytą reikalavim vienuoliui ką nors publikuojant nenurodyti savą asmenț žyminčio vardo a pavardes. Del to, pavyzdžiui, nemaž dalis jézuitu parašytu ir Lietuvoje išspausdintu kưrinil pasirode pseudonimais ar kitu asmenu pavardèmis. Itin iškalbingas čia Motiejaus Kazimiero 